\title{
ASSESSMENT OF DAMS' TROPHIC STATUS AS A TOOL FOR WATER RESOURCES' SUSTAINABLE MANAGEMENT IN MOROCCO: CASE OF THE BOUHOUDA TAOUNATE DAM (MOROCCO)
}

\author{
Aicha HAMID, Oussama BENABBI and Mohammed FEKHAOUI \\ Head of Geo-Biodiversity and Natural Patrimony Laboratory GEOPAC Research Center, \\ Scientific Institute, Mohammed V University, Av. Ibn Batouta, B.P 703, \\ 10106 Rabat, Morocco
}

\begin{abstract}
The Bouhouda's dam was built on Oued Sra, a tributary on the right bank of Ouergha wadi, about $18 \mathrm{~km}$ in the north of Taounate town. The waters of this dam are mainly intended for irrigation and drinking water supply (Ministry of town planning and urban planning, 2014). The aim of this paper is to study the quality and the spatiotemporal evolution of the physicochemical of this dam waters parameters of over a period of eight years (2000/2008) in order to have a better knowledge of the mechanisms and the factors that condition the eutrophication of this lake. A classification has been established based on the Carlson index (1977) (Trophic State Index or TSI) and the Vollenweider index (1968), to identify the trophic state of the reservoir waters. Accordingly, these results can be used for decision support in the context of sustainable development of several nearby dams in the Sbou Basin.
\end{abstract}

Key words: Bouhouda dam, physiochemistry, eutrophication, trophic state, Carlson index, Vollenweider index, Sebou basin.

Cite this Article: Aicha HAMID, Oussama BENABBI and Mohammed FEKHAOUI, Assessment of Dams' Trophic Status as a Tool for Water Resources' Sustainable Management in Morocco: Case of the Bouhouda Taounate Dam (Morocco), International Journal of Advanced Research in Engineering and Technology, 10(5), 2019, pp. 111-125.

http://iaeme.com/Home/issue/IJARET?Volume=10\&Issue $=5$

\section{INTRODUCTION}

Since the beginning of this century, the socio-economic conditions of water use have changed considerably in Morocco, a country with a semi-arid climate, the development of urban agglomerations, the demographic pressure and the limitation of groundwater resources [1] mean that the country has more and more recourse to the superficial waters to satisfy in sufficient quantity, the needs of the populations in drinking and industrial water built [2]. The 
installation of the storage reservoirs plays certainly a positive role given the drawn advantages, but severe part as for the social and environmental continuations. In fact, the health consequences of their construction have been neglected. Such as their contribution in the Greenhouse Gaz production [3] the erosion effects and the risks related to the storage reservoirs [4] Reservoirs present quickly and often signs of silting [5] and eutrophication. The eutrophication is a phenomenon of lakes' aging that leads inevitably to a major order ecological imbalance [6] and which represent the object of our present study. Eutrophication is water enrichment in nutrients, which are primarily phosphorus and nitrogenizes or hyper fertilization [7], these elements support the growth of the plants. It is generally related to anthropic contribution due to arable lands presence, to the purification stations rejections or to the effluents domestic rejections [8]. Eutrophication involves a degradation of the aquatic environments and a reduction of the biodiversity, in consequence of the aquatic ecosystems asphyxiation following a massive algae proliferation, which consume all the oxygen needed for the ecosystem [9]. This deterioration is not without consequences on human health; because it could lead to various diseases such as: cholera, typhoid, hepatitis, bilharziasis and chemical poisoning [10]. This water, of lesser quality, makes the water purification treatment of reservoirs complex and expensive [11].

The purpose of our present study is to determine the causes of eutrophication, its consequences and the share of anthropogenic activity in accelerating its harmful effects on a given lake ecosystem.

\section{MATERIAL AND METHOD}

\subsection{Presentation of the study environment}

The Bouhouda dam was built on Oued Sra, a tributary of Ouergha wadi's right shore, about 18 $\mathrm{km}$ north of Taounate city (Figure 1). The project is located in a region where the geological formations limit groundwater potentialities despite the rainfall importance.The Bouhouda dam is intended for an area irrigation (about $3000 \mathrm{ha}$ ) and for the drinking water supply until 2020 in the center of Bouhouda [11].

The study area climate is warm semi-arid Mediterranean type, where the seasonal contrasts are much accentuated. The rainfall ranges from 350 to $600 \mathrm{~mm}$ and the temperature oscillates between a minimum of $12.5^{\circ} \mathrm{C}$ and a maximum of $37^{\circ} \mathrm{C}$.

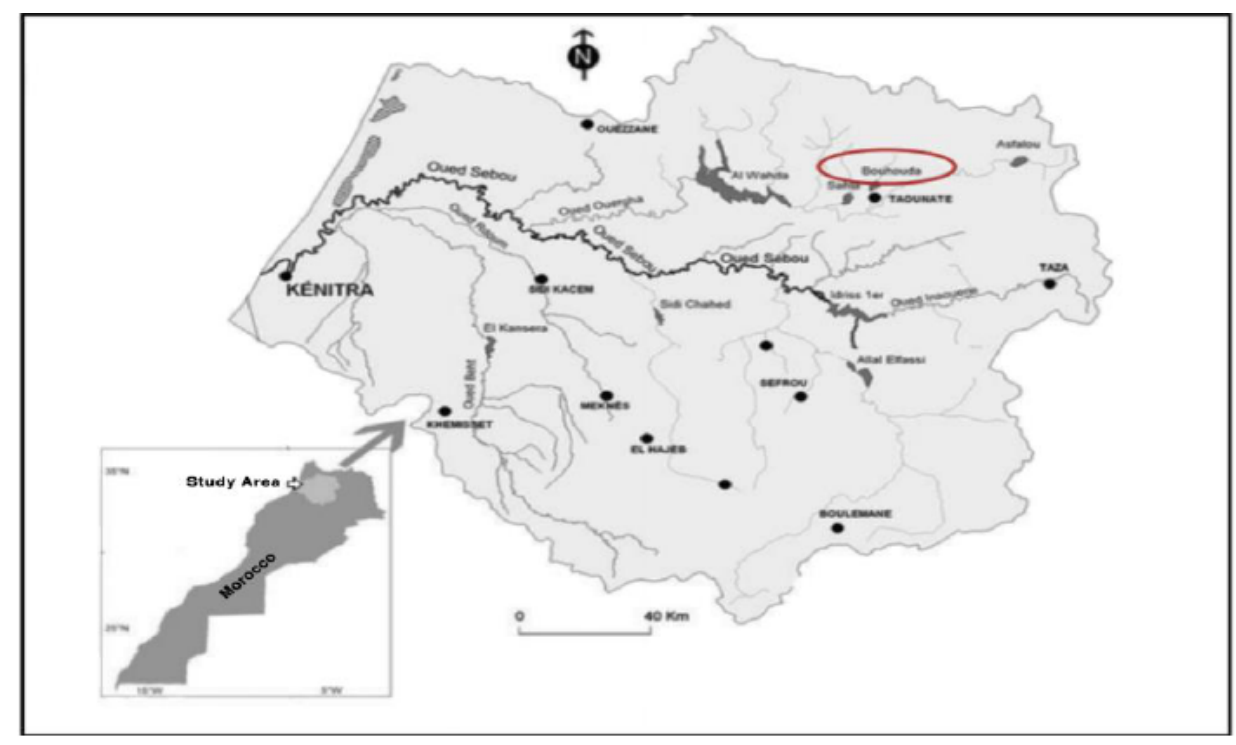

Figure 1 Location of Lake Bouhouda [12] 
Assessment of Dams' Trophic Status as a Tool for Water Resources' Sustainable Management in Morocco: Case of the Bouhouda Taounate Dam (Morocco)

Table 1. Morphometric and hydrological characteristics of the dam lake Bouhouda [13]

\begin{tabular}{|l|l|}
\hline Date of impoundment & 1999 \\
\hline Watercourse & Sra \\
\hline Province & Taounate \\
\hline The nearest town & Bouhouda \\
\hline function & Irrigation / Drinking water supply \\
\hline Overall capacity of the reservoir & $55 \mathrm{Mm} 3$ \\
\hline Average annual contributions & $303 \mathrm{Mm} 3$ \\
\hline Characteristics of the book: Type: & BCR \\
Heights: Volume: & $55 \mathrm{~m}$ \\
& $220.000 \mathrm{~m} 3$ \\
\hline Works duration & 48 month \\
\hline
\end{tabular}

\subsection{Sampling and analysis methods}

The lake was sampled between 09/03/2000 and 06/08/2008 with a sampling frequency of once a month at the catchment level of ONEP [14] in order to study the majority of its physicochemical characteristics (temperature, dissolved oxygen, conductivity, $\mathrm{pH}$, chlorophyll a, transparency, nitrogen elements, orthophosphates and total phosphorus, cations, etc.).

In order to determine the degree of the lake stratification, a profile of temperature, $\mathrm{pH}$ and oxygen was made only twice during 2003 because of the difficulty of access. Therefore, the month June represents the summer season and the month October represents the fall season.

\section{RESULT AND DISCUSSION}

\subsection{Water Balance}

For water supplies, a series of records made from 1942 until 2008, to compare the average inputs in millions of $\mathrm{m} 3$ before and after the impoundment of the Bouhouda dam, are presented below.

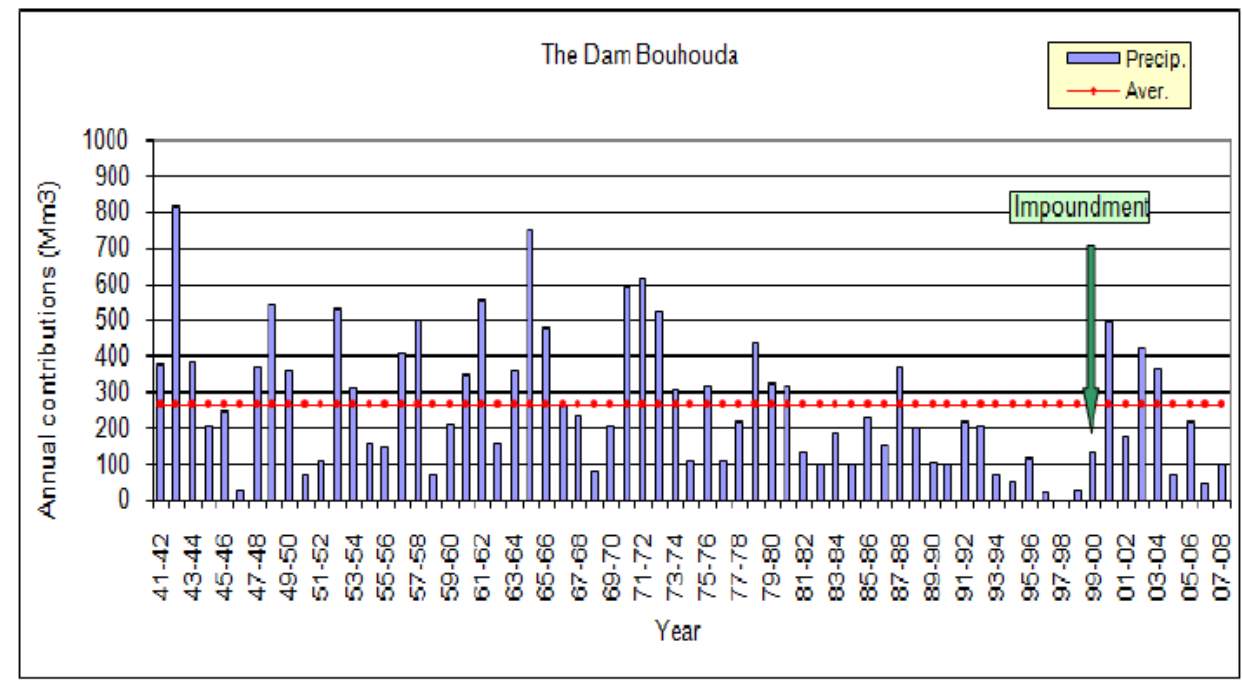




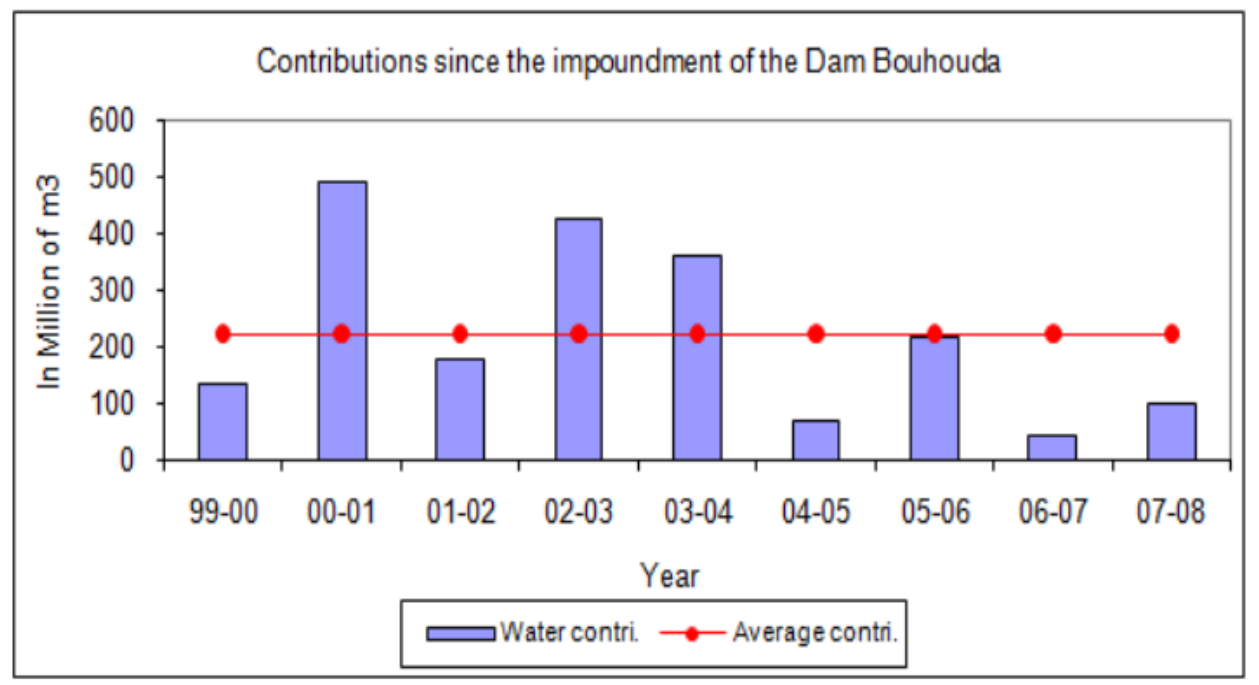

Figure 2 Water supply before and after the Bouhouda dam impoundment

Contributions were irregular from a year to another. The minimum was recorded during 1996-97 and the maximum during 1942-43, respectively 21.1 and 814.1 Mm3. However, the global analysis of these fluctuations since 1999 permit to distinguish that the inputs are much more sustained after the dam impoundment with an average of $225.2 \mathrm{Mm} 3$.

\subsection{Temperatures}

\subsubsection{Seasonal variations}

Considered among the most important ecological factors, water temperature is closely related to a whole set of parameters, its alteration can lead to various ecological consequences [15]. The lake water temperature variations depend on the ambient atmospheric temperature variations, which is as well subject to seasonal variations $(\mathrm{R} 2=0.6687)$ (Figure 3$)$. The presence of a seasonal cycle in this data series is perceptible. This cycle shows that the water temperature is minimal during the cold season and maximal during the hot season, which certainly favors, in the summer period, the development of plankton, an important factor in water purification [16].

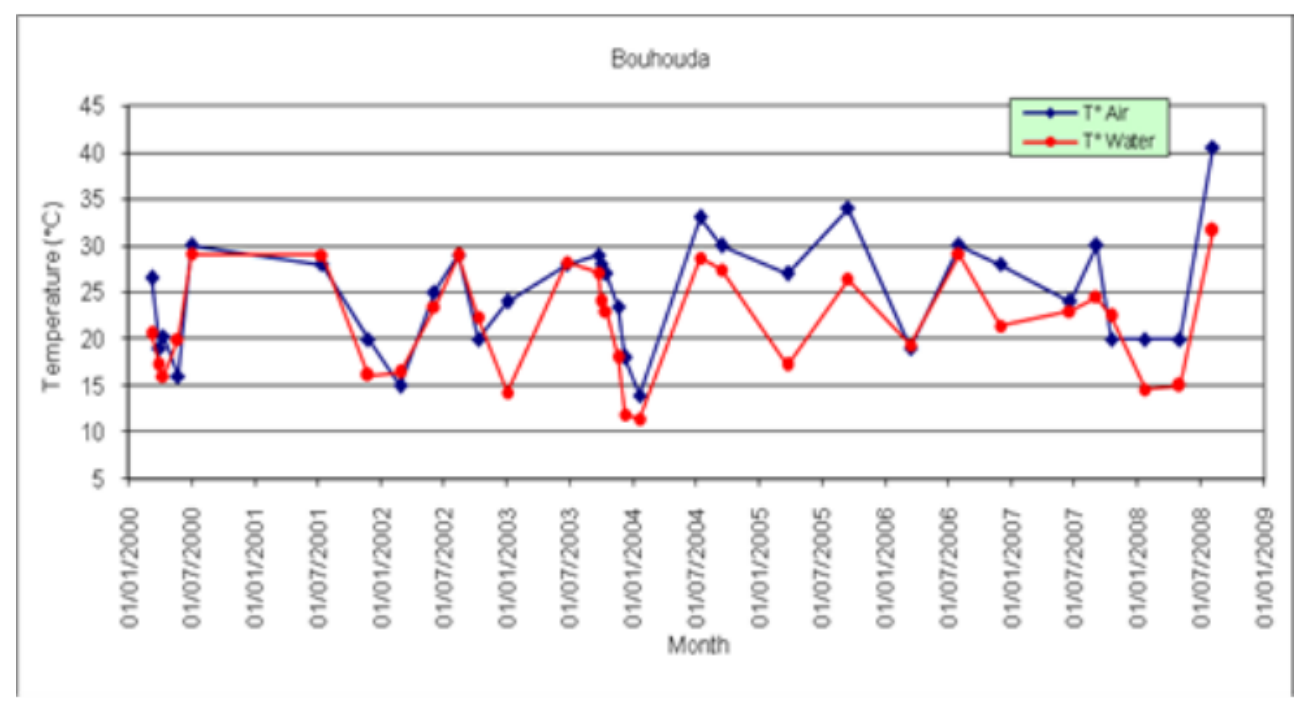

Figure 3 Inter-annual evolution and correlation of Lake Bouhouda water and air temperatures. 
Assessment of Dams' Trophic Status as a Tool for Water Resources' Sustainable Management in Morocco: Case of the Bouhouda Taounate Dam (Morocco)

\subsubsection{Stratification and mixing waters cycle}

A Sudden thermal stratification of the temperature was detected in autumn. The reservoir appears subdivided into a low part called cold hypolimnion and a high part called hot epilimnion, separated by a thermocline located at a depth of 7-9 $\mathrm{m}$, these periods are associated with wet periods (rainfall). Unlike the summer season, there is a less pronounced and progressive thermal stratification to be diffused beyond $15 \mathrm{~m}$ until the total mixing at depth.

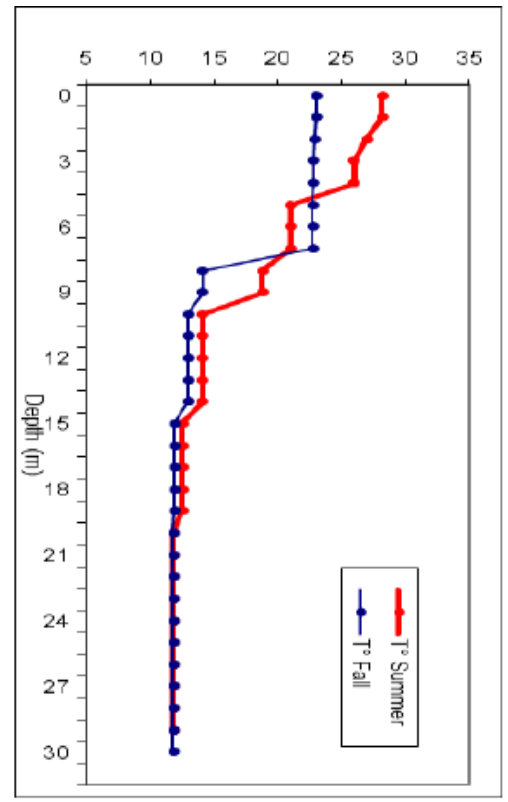

Figure 4 Vertical profiles of seasonal temperature variation in Bouhouda Lake

\section{3. $\mathrm{pH}$}

\subsubsection{Seasonal variations}

The $\mathrm{pH}$ has shown relatively high values between 7.8 and 10.20 . These values are all situated in the VMR range [14] (Figure 5), with a $\mathrm{pH}$ that is above the alkalinity threshold (8.2). This allows us to deduce that the dam water is alkaline. This alkalinity could be due, on one hand, to the biological activity of the aquatic ecosystems (photosynthesis and mineralization of organic matter), on the other hand to the land crossed nature and/or to the Sra wadi water inputs.

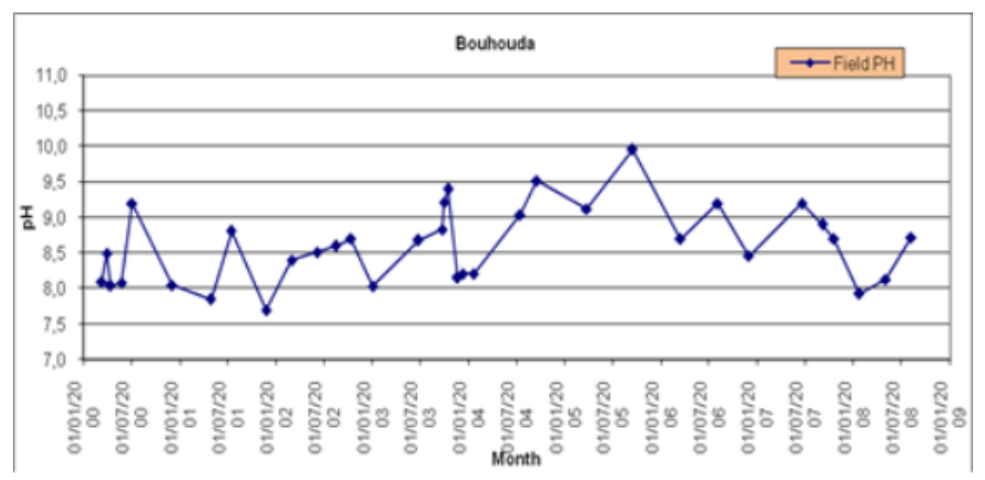

Figure 5 Inter-annual evolution of Bouhouda Lake PH.

\subsection{2. pH stratification state}

Seasonal variations show a very strong and brutal stratification during the wet period (autumn) with the highest values at the surface, unlike the summer period where the stratification is less pronounced and settles progressively. The $\mathrm{pH}$ content decreases considerably between the 
surface, where the activity of photosynthesis is very important (intense light, strong heat), and the depth that is characterised by a lack of light and a lower temperature (reduction of photosynthesis) during the summer and the autumn.

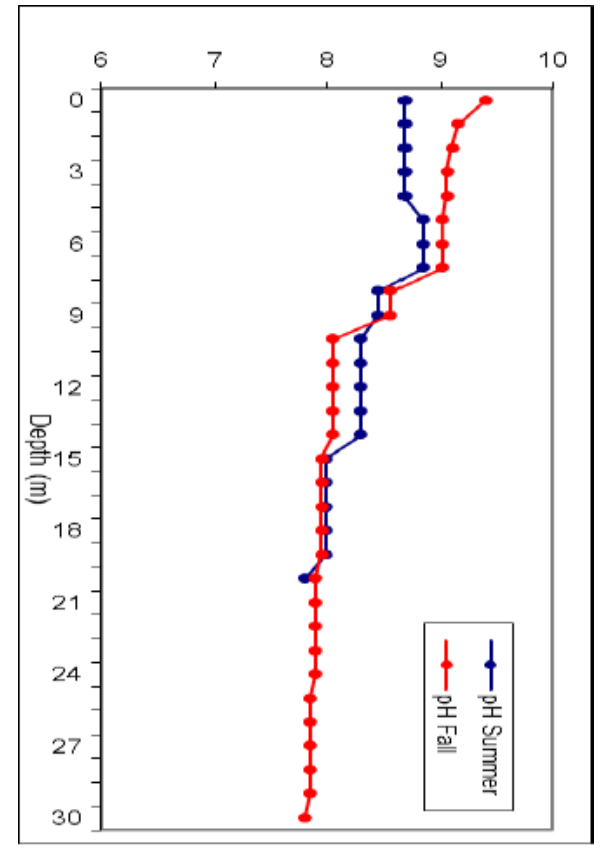

Figure 6. Vertical profiles of $\mathrm{pH}$ seasonal variation in Bouhouda Lake

\subsection{Dissolved oxygen and oxydability}

\subsubsection{Seasonal variations}

Dissolved oxygen is one of the most sensitive parameters to pollution. Its value gives us information on the degree of pollution and consequently on the degree of self-purification of a watercourse [17]. Except the low value founded in 2007 (4.7 $\mathrm{mg} / 1)$, the dissolved oxygen levels reveal that Bouhouda Lake waters are sufficiently oxygenated. Values vary between 6.1 $\mathrm{mg} / 1$ and $11.5 \mathrm{mg} / 1$.

The oxydability measured values are low (good results according to the surface water quality standards). The maximum recorded is 5.1 (05/2000) (figure 9). The minima are in the order of 0.66 and $0.84 \mathrm{mg} / 1$.

The inter-annual evolution is very irregular due to the hydrological conditions instability that characterizes this environment. The average high values would probably coincide with the autumnal photosynthesis of the highly active algal and zooplanktonic biomasses. 
Assessment of Dams' Trophic Status as a Tool for Water Resources' Sustainable Management in Morocco: Case of the Bouhouda Taounate Dam (Morocco)

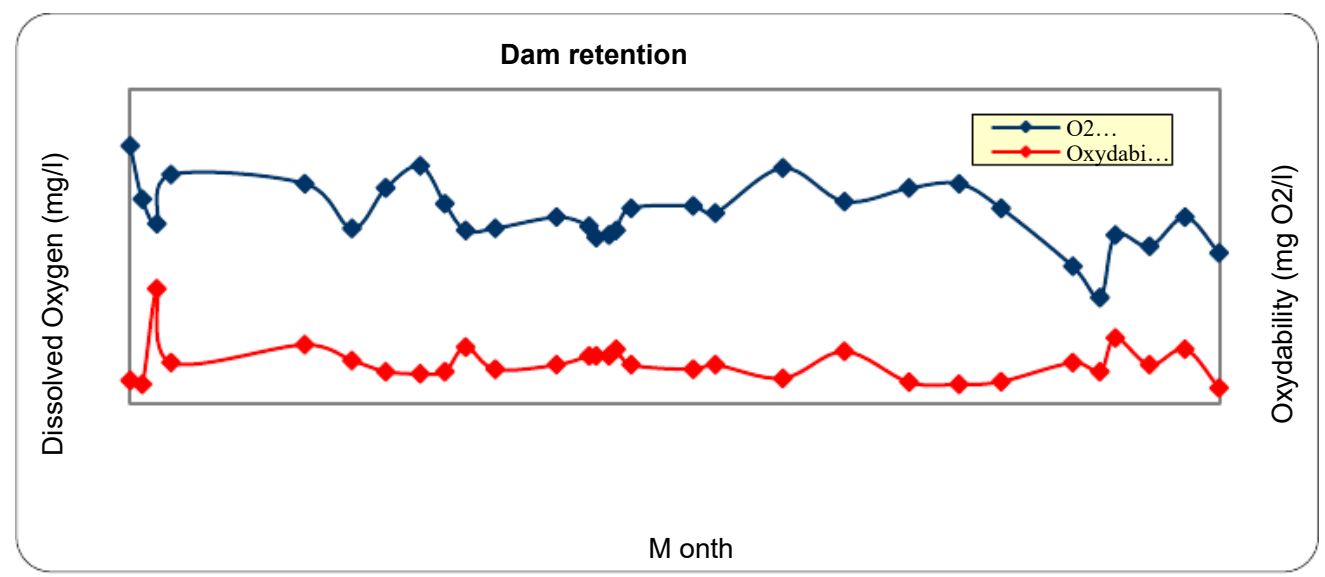

Figure 7 Dissolved oxygen variation and oxydability of Bouhouda Lake.

\subsubsection{Stratification state of dissolved oxygen}

The oxygen vertical profile shows that the summer mixing, even incomplete, has allowed a low reoxygenation of the bottom, however higher concentrations of dissolved oxygen are observed at the surface ( 8.3 and $8.5 \mathrm{mgO} / \mathrm{l})$. Lower in the column, the partial reoxygenation reaches 3.6 $\mathrm{mgO} 2 / 1$ at the bottom; this observation demonstrates that the hypolimnion has a sufficient amount of dissolved oxygen in the summertime.

However the lack of oxygen present in autumn shows a significant deep biodegradation. The average difference in surface-bottom oxygenation is important (figure 8).

The availability of light in the water column is a major physical factor, since that the water transparency plays a dominant role in the dissolved oxygen stratification. Indeed, there is a depth of compensation in terms of dissolved oxygen, defined as the depth where photosynthetic production rates are equal to organisms' respiration rates.

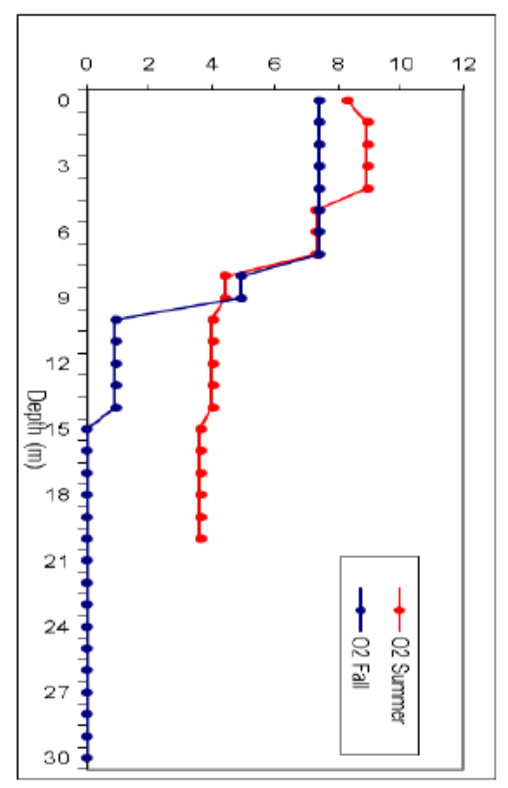

Figure 8 Vertical profiles of seasonal variation Dissolved oxygen in Bouhouda Lake

\subsection{Water Turbidity, Suspended Materials and Dry Residues}

A similarity and a correlation between Bouhouda Lake's turbidity and suspended material (SM) are noticed. 
In fact, turbidity measures the degree of light penetration in the water column. The most important values were recorded in 08/2002 and 01/2004.



Figure 9 Variation and correlation of Bouhouda Lake's turbidity and SM.

For dry residues, all the recorded values do not exceed $300 \mathrm{mg} / 1$, then the lake water remains weakly mineralized.

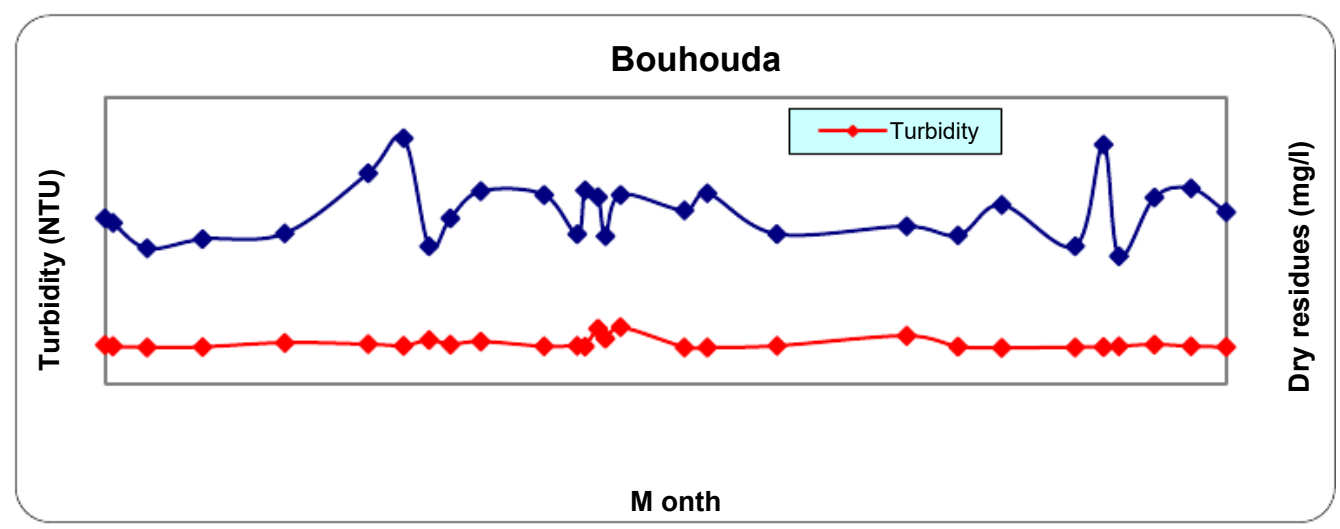

Figure 10 The variation and correlation of Bouhouda Lake turbidity and dry residues.

\subsection{Conductivity}

The lake's conductivity data remains moderate $(<300 \mu \mathrm{S} / \mathrm{cm})$ during the entire sampling period, which indicates that the mineralization and the release of minerals by the decomposition of organic matter are quite low in the lake.

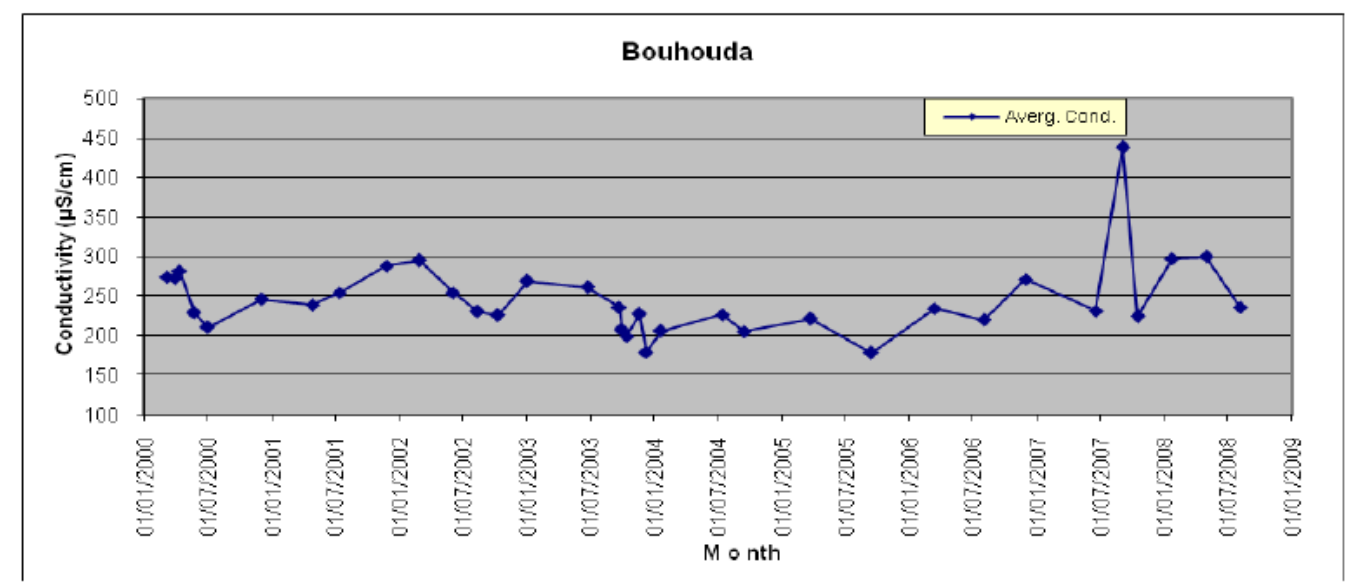

Figure 11 Evolution of the conductivity in $\mu \mathrm{S} / \mathrm{cm}$ in Bouhouda Lake. 
Assessment of Dams' Trophic Status as a Tool for Water Resources' Sustainable Management in Morocco: Case of the Bouhouda Taounate Dam (Morocco)

\subsection{Chlorophyll a}

Chlorophyll (a) is marked by a very high seasonal variability during the study period. The highest concentration $13 \mathrm{mg} / \mathrm{m} 3$; was recorded in 2001, 2002 and 2004 (Figure 12). This fairly important level of chlorophyll (a) reflects the presence of a large phytoplankton biomass; therefore, the water column is quite rich in nutrients.



Figure 12 Inter-annual evolution of chlorophyll (a) in Bouhouda Lake

\subsection{Transparency}

The water's transparency varies irregularly and depends on the hydrological cycles, especially on the phytoplankton and algal productivity. In fact, seasonal variations show that the dam waters are poorly transparent, especially in winter, and relatively transparent in summer and autumn.

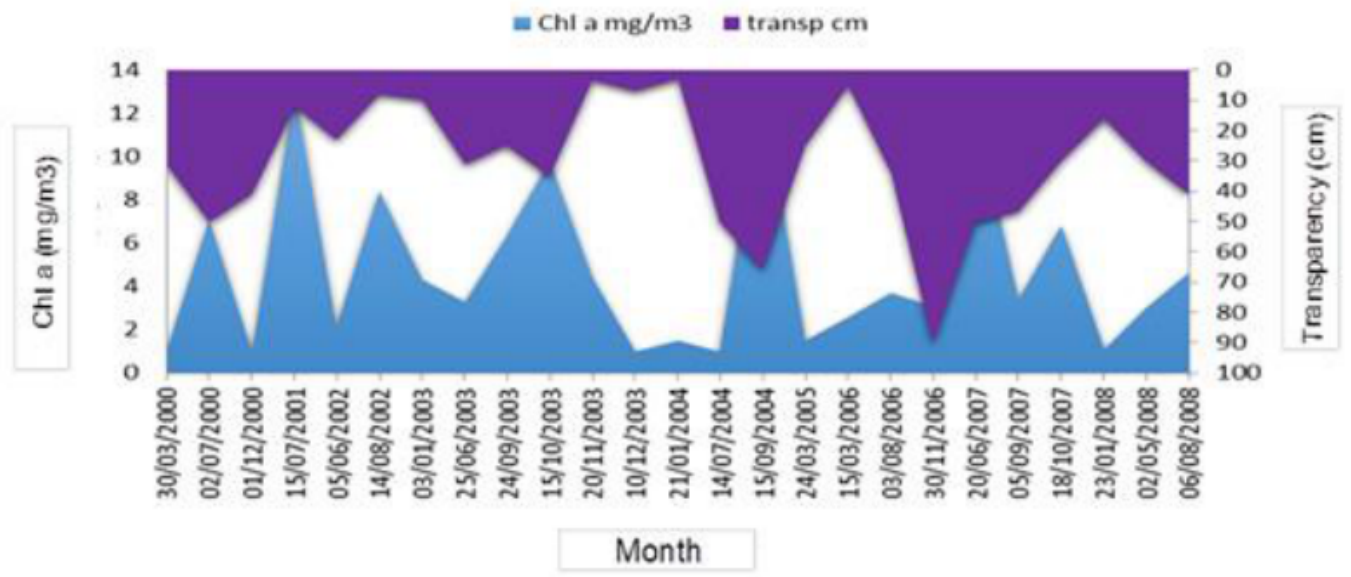

Figure 13 Inter-annual variations in transparency and chlorophyll (a).

The comparison of the chlorophyll (a) and transparency variation profiles (Figure 13) shows some correlation except for few points. This suggests that the lake productivity is the main responsible factor of this state, and not the winter and autumn inflows water (which are heavily loaded with suspended matter). 


\subsection{Nutritional elements}

\subsubsection{Orthophosphates and Phosphorus Total}

Orthophosphates have low variability except a peak in 2001 , where a value of $0.43 \mathrm{mg} / \mathrm{l}$ is recorded (Figure 14). The maximum records of total phosphorus concentrations (PT-P) are 1.6 and $1.9 \mathrm{mg} / \mathrm{l}$, registered respectively in 2002 and 2004. The other values recorded do not exceed the maximum value of $1 \mathrm{mg} / \mathrm{l}$. However, according to the lake water quality grid, the recorded values classify these waters as medium to poor waters.
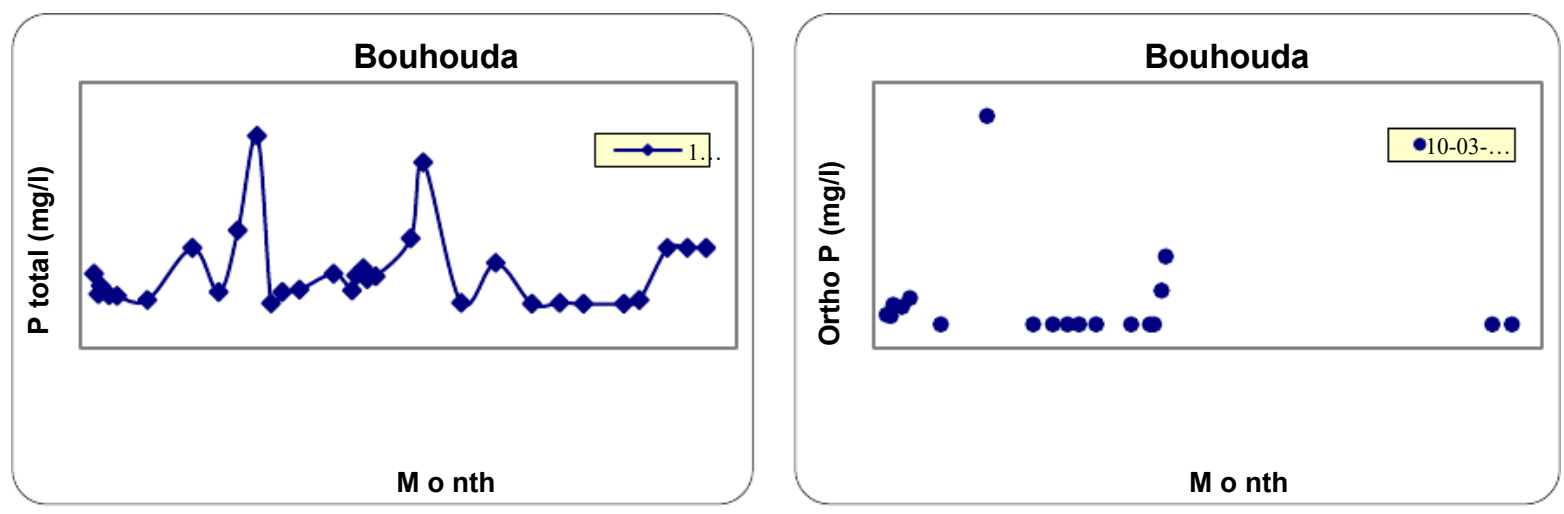

Figure 14 Inter-annual evolution of orthophosphates and total phosphorus.

\subsubsection{Nitrogen salts}

Nitrate contents (NO3-), which represent the essential of the total nitrogen, show significant seasonal variations. They are relatively high in the winter-spring period due to the good water oxygenation combined with the importance of liquid inputs (Figure.15). These grades respect water quality standards (excellent class) $(<10 \mathrm{mg} / 1)$, except few peaks where maximum values between 13.2 and $14.8 \mathrm{mg} / \mathrm{l}$ are recorded.

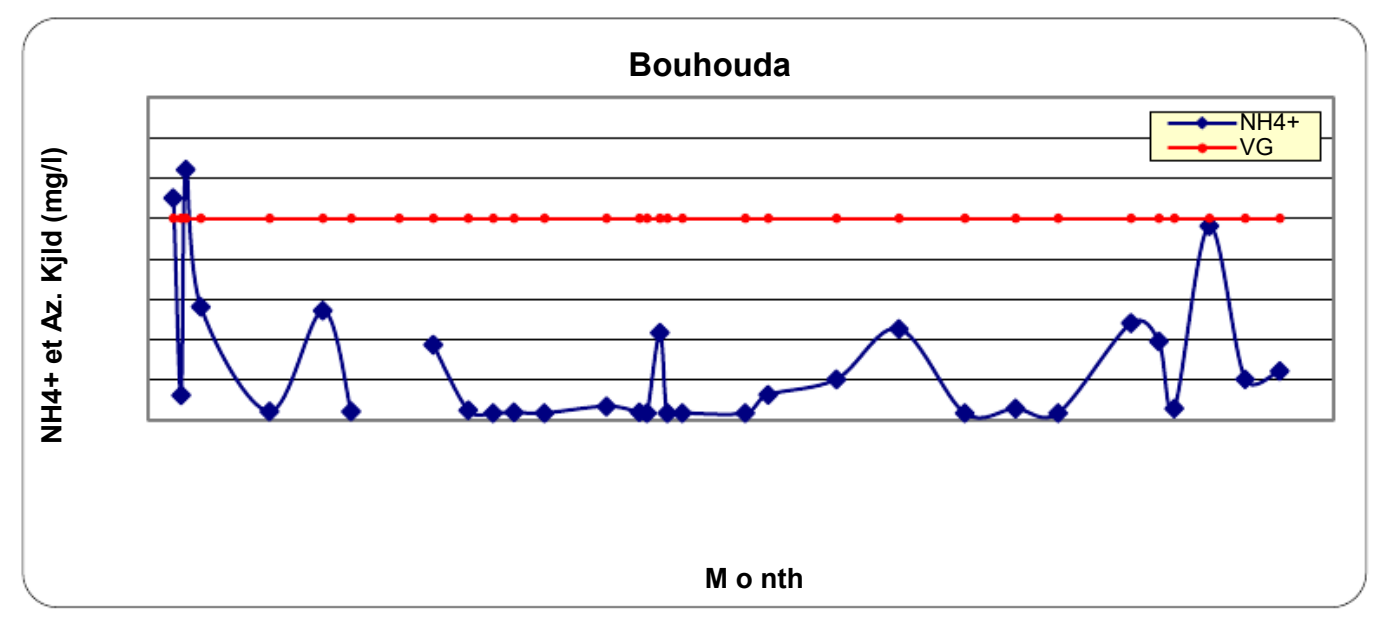

Figure 15 Inter-annual evolution of nitrates.

The contents of N-NH4 are low especially in winter. The highest values are recorded in summer ( 0.55 and $0.48 \mathrm{mg} / 1$ recorded in $04 / 2000,05 / 2008$ respectively). 
Assessment of Dams' Trophic Status as a Tool for Water Resources' Sustainable Management in Morocco: Case of the Bouhouda Taounate Dam (Morocco)

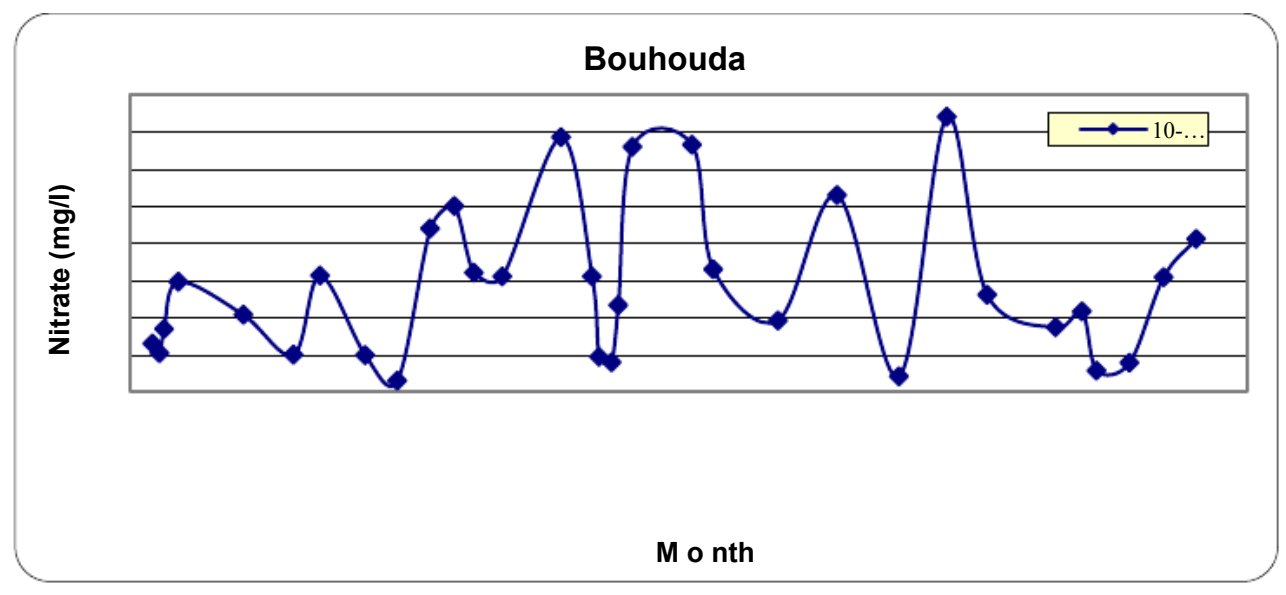

Figure 16 Inter-annual evolution of ammoniacal nitrogen.

Kjeldahl total nitrogen contents (Figure 17) remain very low and fluctuate between 0 and 3 $\mathrm{mg} / \mathrm{l}$ in the water reservoir.

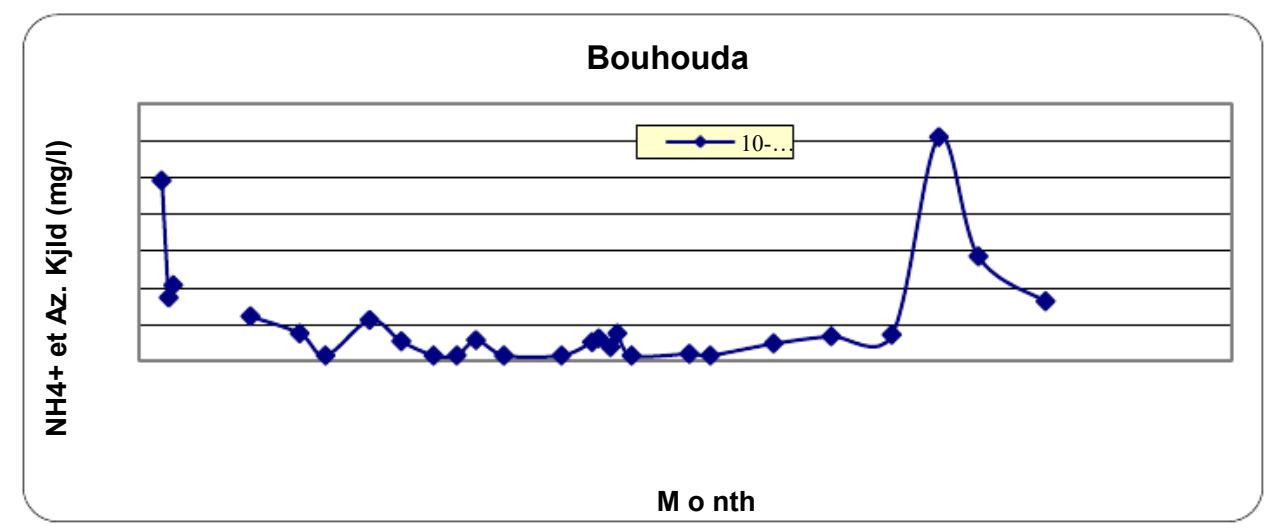

Figure 17 Interannual evolution of Kjeldal Nitrogen

\subsection{Iron and Manganese}

The average iron content varies from 0 to $2.9 \mathrm{mg} / 1$; all values recorded do not exceed the guideline values, except for a few values observed during wet periods in 2000; 2001 and 2003. Concerning manganese, the majority of the values do not exceed the guide values. They vary between $0.01 \mathrm{mg} / 1$ to $0.19 \mathrm{mg} / 1$ except for the years 2007 and 2008 where the recorded contents are respectively 0.19 and $0.12 \mathrm{mg} / 1$.
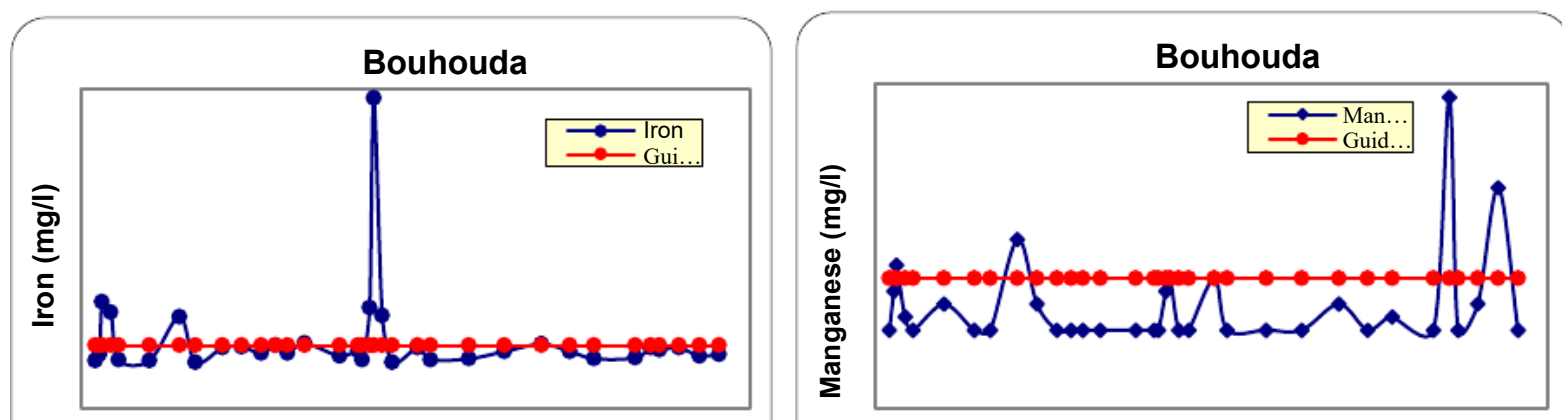

M o nth

M o nth

Figure 18 Evolution of manganese and iron in Bouhouda Lake waters. 


\subsection{Trophic state of Lake Bouhouda}

Used by several authors to identify the trophic state of lakes, the Carlson index [18](Trophic State Index or TSI) is based on the fact that the degree of a lake eutrophication depends on the nutrients' increased concentration, including phosphorus. Generally, the increase in phosphorus concentration results in a microscopic algae increase; as evidenced by the chlorophyll (a) parameter measurements and the transparency decrease.

High values above 50 on the TSI scale are typical of eutrophic lakes with high biological productivity, whereas the values below 40 on the same scale are usually representative of oligotrophic lakes, where the water detains low biological productivity. Intermediate values correspond to mesotrophic lakes.

In the following table the average values of the three considered parameters are reported with their index namely transparency TSI (Secchi), chlorophyll a, PT and their average TSI:

\begin{tabular}{|c|c|c|c|c|}
\cline { 2 - 5 } \multicolumn{1}{c|}{} & $\begin{array}{c}\text { Transparency } \\
(\mathbf{m})\end{array}$ & $\begin{array}{c}\text { Total } \\
\text { phosphorus } \\
(\boldsymbol{\mu g} / \mathbf{L})\end{array}$ & $\begin{array}{c}\text { Chlorophyll } \\
(\boldsymbol{\mu g} / \mathbf{L})\end{array}$ & Average TSI \\
\hline Average values & 0,19 & 377,78 & 4,91 & \\
\hline TSI & 83,93 & 89,72 & 46,21 & 73,28 \\
\hline
\end{tabular}

Based on these TSI indices, Bouhouda lake can be classified as eutrophic hypertrophic.

The same observation is noted by the calculation according to the following diagram.

The transparency index, the total phosphorus index and the chlorophyll (a) index of Bouhouda Lake correspond to the trophic eutrophic to hyper-eutrophic status (according to the diagram in figure 19.

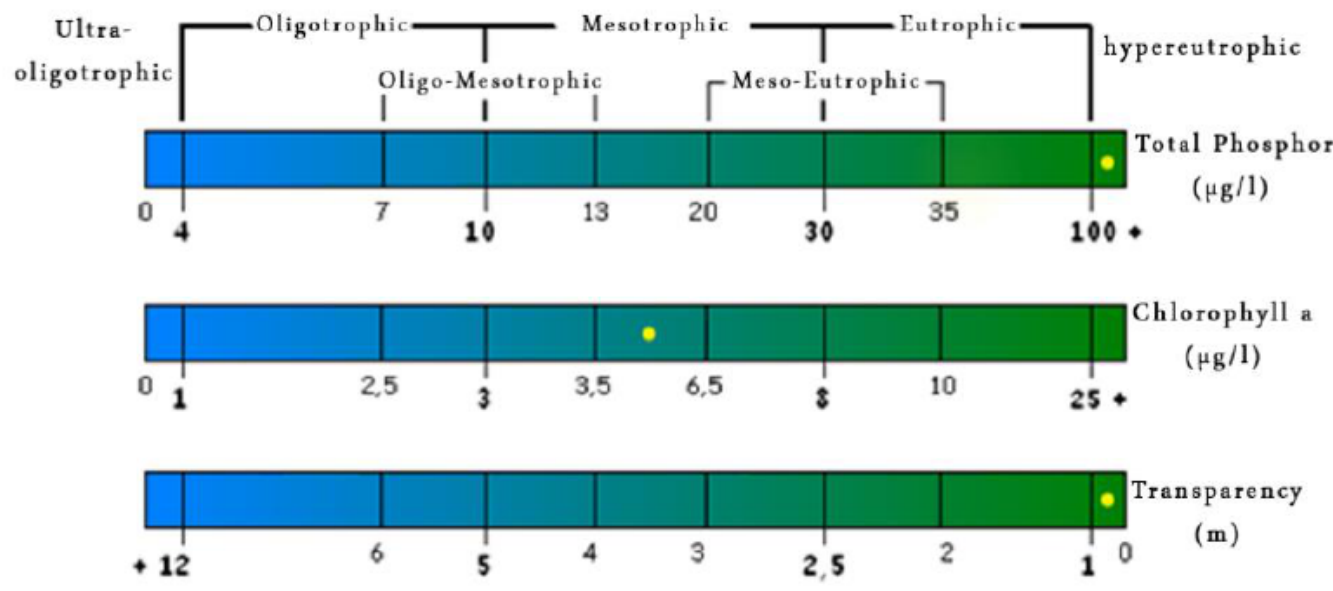

Figure 19 Lake Trophic Level Rank Diagram [19]

In summary, the trophic status of the lake corresponds to a eutrophic hypereutrophic stage. This conclusion is based on the three indices which reveal low water transparency, high phytoplankton biomass and high levels of total phosphorus. 
Assessment of Dams' Trophic Status as a Tool for Water Resources' Sustainable Management in Morocco: Case of the Bouhouda Taounate Dam (Morocco)

Table 2. Lakes classification according to Vollenweider [20]

\begin{tabular}{|c|c|}
\hline Trophic category & Chlorophyll a \\
\hline Ultra-oligotrophic & $<1$ \\
Oligotrophic & $<2,5$ \\
Mesotrophic & $2,5-8$ \\
Eutrophic & $8-25$ \\
hypereutrophic & $>25$ \\
\hline
\end{tabular}

Thus, the trophic status of the Bouhouda reservoir-lake, based on the general average of chlorophyll (a) and the Vollenweider's classification (1968), is also classified as hypereutrophic lakes (Table 1).

\section{CONCLUSIONS}

The limnological diagnosis of the Bouhouda dam allowed us to note several particularities:

- The body water stratification and mixing regime is a monomictic body of water with a thermal stratification that usually extends during the cold wet season of the year.

The thermocline created forms a barrier which prevents the well-oxygenated water transport from the epilimnion to the hypolimnion. The production of microscopic algae in the superficial layers is due to the light penetration which, in the presence of nutrients, causes an excessive sedimentation of detritus. This sedimentation produces deoxygenation of the hypolimnion where the anaerobic conditions are established and tend to rise very high in the water column particularly in the summer season.

- Due to the presence of sufficient nitrates, which act as additional oxidizing material, bacteria do not need to use the sulphates in the organic material decomposition processes, and therefore there is no Hydrogen sulphide release, however iron, manganese, and ammonium are presents. - The Bouhouda dam water has a relatively high concentration on total phosphorus, a very low transparency and a significant deficit in oxygen at the level of the hypolimnion. The Bouhouda dam is classified in a eutrophic state to a hyper-eutrophic situation.

- If total phosphorus concentrations in the lake are maintained around the current load, and as long as there are no long periods with poor water mixing and a prolonged anoxia in the bottom waters of the lake, a strong release of phosphorus sediment would certainly be caused. This would maintain the lake in a hyper-eutrophic state.

These results could contribute to establish specific programs and actions to reduce phosphorus inputs according to the use of water, and to improve the water quality management in terms of trophic response as part of a sustainable development program. It would be interesting to complete this study with future work based on the mathematical modeling of the lakes trophic states in order to carry out prevention procedures capable of curbing the eutrophication phenomenon of the other Mediterranean water reservoirs.

\section{REFERENCES}

[1] Jellali Mohammed M., (1997). Water Resources Development in Morocco, Mediterranean Options, SéE A / n031, Méditenanéens Seminars.

[2] Chahboune M., Chahlaoui A., Zaid A., (2014). Étude de la qualité des eaux d'une retenue située sous climat aride : cas du barrage Hassan II (Province de Midelt, Maroc)

[3] Pigeon J L., (2004). Reservoirs and greenhouse gas emissions: Consequences for hydropower.

[4] Chocat B., (2014). Are dams a good for the environment? 
[5] Badraoui A.,Hajji A.(2001). Siltings of dams, Sitting in dam basins, The White Hole Number 6-7, October 2001

[6] EL Ghachtoul Y. M. Alaoui Mhamidi, Gabi H., (2005). Eutrophication of reservoirs at Smir and Sehla dams (Morocco): causes, consequences and management instructions smir sehla dam, Journal of Water Science volume 18, p 75-89.

[7] Grouz N A., (2015). Eutrophication and dynamics of phosphorus and nitrogen in Seine : a new context following the improvement of wastewater treatment. Biochemistry, Molecular Biology. Université Pierre et Marie Curie-ParisVI. 8. Bouloud A., Foutlane A., Bourchich L., (2001). Eutrophication of dam reservoirs and production of drinking water. H.T.E. 119: 21-24.

[8] Kemmou S., (2011). Seasonal variations and potential mobility of sedimentary phosphorus in the Al Massira dam dam (Morocco). PhD thesis of the Faculty of Sciences Rabat. : 223 p.

[9] CNRS, 2008: National Center for Scientific Research (Fr).

[10] Abdallaoui A., (1998): Contribution to the study of phosphorus and heavy metals contained in sediments and their influence on eutrophication phenomena and pollution. Case of the watershed of Wadi Beht and El Kansera Dam. PhD Thesis, Université Moulay Ismail. Faculty of Sciences of Meknes: 290.

[11] EL Ouali Lalami A., Merzouki M., El Hillali O., Maniar S., Ibnsouda, Koraichi S., (2011). Pollution of surface water in the city of Fez in Morocco: Typology, origin and consequences. Larhyss Journal. 9.: 55-72.

[12] Jaouda, A. Akhssas, L. ouadif, L. bahi , A. lahmili ., 2017 Stabilité des talus et impact sur le réseau routier: cas du bassin versant d'Ouergha (Maroc).

[13] Ministry of Town Planning and Urban Planning, Urban Agency of Taza, Development Plan of the center of Bouhouda, Presentation Note March 2014

[14] ONEP, 1996: Fight against the eutrophication of the reservoir lake Sidi Mohammed Ben Abdellah. Introduction of the silver carp of China. (1991) $41 \mathrm{p}$

[15] Leynaud G., 1968 Les pollutions thermique, influence de la température sur la vie aquatique. B.T.I. Ministère de l'agriculture, pp. 224-881.

[16] Tifnouti A., (1987). Dynamics of a population of Moina micrura (Crustacea, Cladocera) in a lagoon in Marrakech (Morocco)

[17] Makhoukh M., Sbaa M., Berrahou A., Van Clooster M., 2011 Contribution à l'étude physico-chimique des eaux superficielles de l'oued Moulouya (Maroc oriental). Larhyss Journal 9:149-169.

[18] Carlson R E. ,1977 A trophic state index for laks, Limnology and Oceanography. 22 :361369.

[19] Ministry of Sustainable Development, Environment and the fight against climate change (MDDELCC). 2015b. The voluntary monitoring network of lakes: Methods. Online: http://www.mddelcc.gouv.qc.ca/eau/rsvl/methodes.htm. Accessed February 18, 2015.

[20] Vollenweider, R.A. (1968). Scientific fundamentals of the eutrophication of lakes and flowing waters, with particular reference to nitrogen and phosphorus as factors of eutrophication. O.C.D.E. Paris, Technical Report, DA 5 / SCI / 68.27, 250 p.

[21] Kadhim Naief kadhim Al-taee, Thair Jabbar Mizhir Al-Fatlawi and Zainab Falah Hussein Al-Barrak (2015), Lowering Groundwater in the Archaelogical Babylon City Using Underground Dams, International Journal of Civil Engineering and Technology (IJCIET), Volume 6, Issue 4, April (2015), pp. 107-119 
Assessment of Dams' Trophic Status as a Tool for Water Resources' Sustainable Management in Morocco: Case of the Bouhouda Taounate Dam (Morocco)

[22] Ajith A.V and Dr. Abdu Rehman K.U. (2014), Sediment Flow Changes Induced by Dams in Pamba River, International Journal of Civil Engineering and Technology (IJCIET), Volume 5, Issue 12, December (2014), pp. 211-218.

[23] SS.Asadi, N.Vijay Kumar, K. Rajyalakshmi and M. Satish Kumar (2017), Designee of Water Harvesting Structures for Water Resources Management: A Model Study from Chelila Watershed, Bhutan, International Journal of Mechanical Engineering and Technology 8(10), 2017, pp. 666-679.

[24] Lomova L. A, Epifancev K. V, Zhminko N. S, Romanova T. I, Bolshanik P. V and Goneev I.A (2018), Use of Underground Water Resources in Regions with Intensive Human Management Activities, International Journal of Mechanical Engineering and Technology, 9(13), 2018, pp. 595-607. 